\title{
Potential of laticifer fluids for inhibiting Aedes aegypti larval development: evidence for the involvement of proteolytic activity
}

\author{
Márcio V Ramos ${ }^{1 /+}$, Danielle A Pereira1, Diego P Souza1, Eliane S Araújo ${ }^{1}$, Cléverson DT Freitas ${ }^{1}$, \\ Mariana G Cavalheiro', Mayara Patricia V Matos' ${ }^{1}$ Ana FU Carvalho²/+
}

1Departamento de Bioquímica e Biologia Molecular ${ }^{2}$ Departamento de Biologia, Universidade Federal do Ceará, Campus do Pici, Caixa Postal 6033, 60451-970 Fortaleza, CE, Brasil

It has been shown previously that the laticifer fluid of Calotropis procera (Ait.) R.Br. is highly toxic to the egg hatching and larval development of Aedes aegypti L. In the present study, the larvicidal potential of other laticifer fluids obtained from Cryptostegia grandiflora R.Br., Plumeria rubra $L$. and Euphorbia tirucalli L. was evaluated. We attempted to correlate larvicidal activity with the presence of endogenous proteolytic activity in the protein fraction of the fluids. After collection, the fluids were processed by centrifugation and dialysis to obtain the soluble laticifer protein (LP) fractions and eliminate water insoluble and low molecular mass molecules. LP did not visibly affect egg hatching at the doses assayed. LP from Cr. grandiflora exhibited the highest larval toxicity, while P. rubra was almost inactive. E. tirucalli was slightly active, but its activity could not be correlated to proteins since no protein was detected in the fluid. The larvicidal effects of LP from C. procera and $\mathrm{Cr}$. grandiflora showed a significant relationship with the proteolytic activity of cysteine proteinases, which are present in both materials. A purified cysteine proteinase (papain) from the latex of Carica papaya (obtained from Sigma) was similarly effective, whereas trypsin and chymotrypsin (both serine proteinases) were ineffective. The results provide evidence for the involvement of cysteine proteinase activity in the larvicidal action of some laticifer fluids. C. procera is an invasive species found in areas infested with Ae. aegypti and thus could prove useful for combating mosquito proliferation. This is the first report to present evidence for the use of proteolytic enzymes as chemical agents to destroy Ae. aegypti larvae.

Key words: Aedes aegypti - biological control - cysteine proteinases - latex - larvae - papain

Dengue fever, recognised by the WHO as a "major international public health concern" (WHO 2009), peaked in Brazil in 1998 with 528,388 cases and again in 2002 with 784,000 cases (Siqueira Jr et al. 2005). According to data published by the Brazilian government, 438,949 cases of classic dengue and 926 cases of yellow fever were registered in Brazil in 2007. Since January 2008 , the whole country has experienced an explosion in the number of new cases that reached one per minute in Rio de Janeiro (PAHO/WHO 2008). However, these statistics may be underestimates due to unreported cases. Regardless, the problem has become more critical each year, likely as a result of unsuccessful governmental actions. Strategies to combat the mosquito vector are still limited, but include the dissemination of chemicals and/or insecticidal bacteria in the environment. In fact, synthetic pesticides, chitin synthesis inhibitors (BPU's), hormone analogues and some bacterial species have been the only chemical and biological strategies developed to reduce insect proliferation (Braga \& Valle 2007). However, such strategies have

Financial support: FUNCAP, CNPq, PADCT, RENORBIO, International Foundation for Science (3070-3 to MVR)

+ Corresponding authors: vramos@ufc.br

Received 11 November 2008

Accepted 21 July 2009 proven to be relatively ineffective or undesirable due to the development of resistance in mosquito populations, negative environmental impacts and the fact that the bacteria show rapid sedimentation from the larval feeding zone, UV light sensitivity and a narrow host range that has hampered their development (Porter 1996). In light of these problems, the search continues for new sources of natural products that could be applied to combating the spread of dengue. Increasing insecticide resistance requires the development of strategies for prolonging the use of highly effective vector control compounds. The use of combinations of multiple insecticides and phytochemicals is one such strategy that may be suitable for mosquito control. New sources of natural materials have been reported in the literature that can inhibit growth, reproduction and oviposition (Consoli \& Oliveira 1994) or act as repellents (Carvalho et al. 2003). We previously described the effects of latex from Calotropis procera (Ait.) R.Br. (Apocynaceae) on egg hatching and larvae of Aedes aegypti (L.) (Diptera: Culicidae) (Ramos et al. 2006). Furthermore, after centrifugation and dialysis steps, two fractions prepared from the crude latex were equally effective at very low doses $(200 \mu \mathrm{g} / \mathrm{mL})$. The protein fraction, which we have termed laticifer proteins (LP), exhibited a relevant toxicity against both eggs and larvae of Ae. aegypti. We are currently in the process of biochemical and toxicological characterisation of this material to determine its potential for use in the fight against the dengue mosquito. 
In the present study, the larvicidal effects of other laticifer fluids were investigated. In addition, we determined the contribution of endogenous proteolytic activity (commonly present in latex fluids) to the larvicidal effect.

\section{MATERIAL AND METHODS}

Chemicals - N- $\alpha$-benzoyl-DL-arginine $\beta$-naphthylamide hydrochloride (BANA), trans-epoxysuccinyl1-leucylamido (4-guanidio)-butane (E-64), ethylenediaminetetraacetic acid (EDTA), ethylene glycolbis( $\beta$-aminoethyl ether) N,N,N',N'-tetra acetic acid, phenylmethylsulphonylfluoride, 4-(dimethyl-amino) cinnamaldehyde, pepstatin, papain (EC 3.4.22.2), trypsin type I from bovine pancreas, (EC 3.4.21.4), chymotrypsin (EC 3.4.21.1) and azocasein were purchased from Sigma Chemical Co. (St. Louis, MO, USA). Iodoacetamide (IAA), Coomassie brilliant blue (R-350) and molecular mass markers were from Amersham Biosciences (Uppsala, Sweden). Bovine serum albumin (BSA) was from Inlab (lot 826.787). All other chemicals were of analytical grade.

Plant material - Healthy and non-cultivated plants of C. procera (Ait.) R.Br., Cryptostegia grandiflora R.Br., Plumeria rubra L. (all Apocynaceae) and Euphorbia tirucalli L. (Euphorbiaceae) growing in the vicinity of Fortaleza-Brazil, were used as the source of fresh latex. Each plant sample was identified by the botanist Edson Paula Nunes and the vouchers 32663 (C. procera), 040409 (Cr. grandiflora), 15018 (P. rubra) and 38702 (E. tirucalli) were deposited at the Prisco Bezerra Herbarium of the Universidade Federal do Ceara, Fortaleza, Brazil. C. procera is an invasive species, occurring throughout Northeast Brazil. This plant produces generous amounts of latex and thus its availability is not a limiting factor for use.

Latex processing - The latex of C. procera was collected from healthy plants by small incisions near the youngest leaves and the liquid was left to flow into distilled water to produce a $1: 1(\mathrm{v} / \mathrm{v})$ mixture. The other latices were collected from the ends of branches and processed following the same procedure detailed below. The mixtures (water and latex) were gently stirred during collection to overcome the tendency of the latices to coagulate. The samples were centrifuged at $5,000 \mathrm{~g}$ for $10 \mathrm{~min}$ at $4{ }^{\circ} \mathrm{C}$. The rubber-like precipitates produced after centrifugation were discarded and the supernatants were exhaustively dialysed against distilled water using membranes of 8,000 molecular mass cut-off. Each sample was maintained for $60 \mathrm{~h}$ at $8^{\circ} \mathrm{C}$ and the dialysis water was renewed three times daily. The retained materials were centrifuged again using the conditions described above. The clean, rubber-free supernatants were lyophilised and used in all subsequent experiments. This procedure eliminates water-insoluble and low molecular mass molecules while retaining almost all proteins.

Eggs and larvae of Ae. aegypti - Eggs of Ae. aegypti were obtained from Núcleo de Endemias Transmissíveis por Vetores (NUVET), Secretaria de Saúde, Ceará, Brazil. The eggs were deposited on paper strips, submerged in distilled water containing $1 \%$ ethanol (1 L) and allowed to develop at $25-28^{\circ} \mathrm{C}$ under a $12-\mathrm{h}$ light/dark cycle until reaching the third larval stage. About $20 \mathrm{mg}$ of soybean seed flour was added to the water as a nutrient source.

Insecticidal bioassays - The bioassays were developed according to WHO procedures (2005) but on a laboratory scale to allow the simultaneous evaluation of bioactivity and investigation of biochemical parameters. Larger-scale assays are currently being planned in accordance with NUVET strategies.

To investigate the effect of LP on egg hatching, the lyophilised LP fractions were dissolved in distilled water containing $1 \%$ ethanol to achieve $1 \mathrm{mg} / \mathrm{mL}$. The LP fraction at this concentration is able to inhibit egg hatching and is active against third instars (Ramos et al. 2006). BSA was used as a negative control. All solutions were prepared immediately before use. Undamaged eggs of Ae. aegypti adsorbed on dry paper strips $\left(1 \mathrm{~cm}^{2}\right)$ were selected, counted and subsequently placed in test tubes containing $10 \mathrm{~mL}$ of each sample in triplicate. Egg hatching was monitored at 24 and $72 \mathrm{~h}$. The assay was conducted at $25-28^{\circ} \mathrm{C}$ and under a dark/light cycle of $12 \mathrm{~h}$. Ethanol (1\%) in distilled water without protein was also used as control.

Assays to evaluate the toxicity of LP and of the purified proteolytic enzymes EC 3.4.22.2, EC 3.4.21.1 and EC 3.4.21.4 to third instars were carried out as follows: larvae were grown as described above. LP were dissolved in distilled water containing $1 \%$ ethanol (as recommended by WHO) at $1 \mathrm{mg} / \mathrm{mL}$, excepting LP of $C$. procera and $\mathrm{Cr}$. grandiflora, which were tested at different concentrations and conditions [with or without dithiothreitol (DTT) and IAA] to investigate correlations between toxicity and proteolytic activity. The purified enzymes listed above were dissolved in $50 \mathrm{mM}$ PBS buffer (pH 6.0 for EC 3.4.22.2 or $\mathrm{pH} 7.0$ for trypsin and EC 3.4.21.1) containing $1 \%$ ethanol. Ten millilitres of each LP sample were added to glass tubes $(20 \times 100 \mathrm{~mm})$ in triplicate and 10 third instars were then added into each tube. Care was taken to use only undamaged individuals. The assays were conducted under a 12-h light/dark cycle at $28^{\circ} \mathrm{C}$ for $48 \mathrm{~h}$. Results were collected at 1, 3, 24 and $48 \mathrm{~h}$ after inoculation. Three independent experiments were performed. Upon completion of the experiments, the larvae were disposed of following a $30 \mathrm{~min}$ boiling treatment.

Samples of $C$. procera and $C r$. grandiflora were prepared as described above at different concentrations, mixed with $3 \mathrm{mM}$ DTT and maintained at $25^{\circ} \mathrm{C}$ for 10 min before the addition of larvae. Similarly, samples were treated with DTT followed by E-64 $(12 \mu \mathrm{M})$ and maintained at $25^{\circ} \mathrm{C}$ for additional 30 min prior to the assay. DTT acts as an activator of cysteine proteinase enzymes and cysteine proteinase activity is found in LP from C. procera (Freitas et al. 2007). E-64 and IAA are both potent and irreversible inhibitors of cysteine proteinase proteolytic activity (Patel \& Jagannadham 2003).

Protein determination - Protein content was measured according to Bradford's procedure with bovine serum albumin as the protein standard (Bradford 1976). 
Electrophoresis - Electrophoresis of proteins was performed to visualise the proteins from LP samples and to develop zymograms. Polyacrylamide gel electrophoresis in the presence of sodium dodecyl sulphate (SDS) (PAGE-SDS) and 2-mercaptoethanol was performed as described by Laemmli (1970). Protein samples were dissolved in sample buffer [0.0625 M Tris buffer ( $\mathrm{pH}$ 6.8) containing $2 \% \mathrm{SDS}$. Electrophoresis was performed at $25 \mathrm{~mA}$ per gel at $25^{\circ} \mathrm{C}$ for $4 \mathrm{~h}$. Gels were stained with Coomassie brilliant blue (R-350) solution in water: acetic acid: methanol (8/1/3.5, v/v/v) and then de-stained with the same solution minus the dye.

Total proteolytic activity - Azocasein was used as a non-specific substrate to investigate total proteolytic activity in LP from Cr. grandiflora, P. rubra and E. tirucalli. A detailed study about the proteolytic activity of latex from $C$. procera was recently published (Freitas et al. 2007) and in the present work, we only sought to characterise the toxicity to Ae. aegypti. The reaction mixture contained 50 or $100 \mu \mathrm{L}(1 \mathrm{mg} / \mathrm{mL})$ of the LP pre-incubated with $3 \mathrm{mM}$ DTT for $10 \mathrm{~min}$. Then, $200 \mu \mathrm{L}$ of $1 \%$ azocasein in $50 \mathrm{mM}$ PBS buffer ( $\mathrm{pH}$ 6.0) was added. The reactions were performed at $37^{\circ} \mathrm{C}$ and stopped $60 \mathrm{~min}$ later by adding $300 \mu \mathrm{L}$ of $20 \%$ trichloroacetic acid. The tubes, in triplicate, were centrifuged $\left(5,000 \mathrm{~g}\right.$ for $10 \mathrm{~min}$ at $\left.25^{\circ} \mathrm{C}\right)$ and the supernatants were alkalinised with $400 \mu \mathrm{L}$ of 2.0 $\mathrm{N} \mathrm{NaOH}$ solution. The absorbance of the sample at $420 \mathrm{~nm}$ was then measured (Xavier-Filho et al. 1989). One unit of activity (AU) was defined as the amount of enzyme capable of changing the absorbance at $420 \mathrm{~nm}$ by 0.01 .

Assays for cysteine proteinases (EC 3.4.22) were conducted utilising BANA as substrate. Aliquots of $100 \mu \mathrm{L}$ of the LP $[1 \mathrm{mg} / \mathrm{mL}$ for C. procera, P. rubra, E. tirucalli and $0.5 \mathrm{mg} / \mathrm{mL}$ Cr. grandiflora in $50 \mathrm{mM}$ PBS ( $\mathrm{pH}$ 6.0)] were pre-incubated with $40 \mu \mathrm{L}$ of an activation solution in the presence of $3 \mathrm{mM}$ DTT and $2 \mathrm{mM}$ EDTA for $10 \mathrm{~min}$. Then, $200 \mu \mathrm{L}$ of BANA was added [1 mM in $50 \mathrm{mM}$ PBS (pH 6.0)]. After $30 \mathrm{~min}$, at $37^{\circ} \mathrm{C}$, the reactions were stopped by adding $500 \mu \mathrm{L}$ of $2 \%$ $\mathrm{HCl}$ in ethanol and $500 \mu \mathrm{L}$ of $0.06 \% 4$-(dimethyl-amino) cinnamaldehyde. Forty minutes later, the absorbance of the samples was measured at $540 \mathrm{~nm}$ (Abe et al. 1992). One AU was defined as the amount of enzyme that increases the absorbance at $540 \mathrm{~nm}$ by 0.01 . All assays were performed in triplicate. The results of each series were expressed as the mean value \pm SEM. EC 3.4.22.2, the cysteine proteinase purified from the latex of Carica papaya (obtained from SIGMA), was assayed for both proteolytic and larvicidal activities for use as a reference. As an additional attempt to verify whether other proteolytic activity besides cysteine proteinase was associated with larval death, EC 3.4.21.4 and EC 3.4.21.1, both serine proteinases (obtained from Sigma), were assayed at 0.05 and $0.1 \mathrm{mg} / \mathrm{mL}$ in $50 \mathrm{mM}$ phosphate buffered saline $\mathrm{pH} 7.0$ (PBS) with azocasein (1\%) as the substrate and tested for larvicidal activity as described above.

Detection of proteases by zymography - Electrophoresis was carried out according to the method described by Schagger and Jagow (1987). LP fractions were dissolved in $1 \mathrm{M}$ Tris- $\mathrm{HCl}$ buffer ( $\mathrm{pH}$ 6.8) containing $10 \%$
SDS, 10\% glycerol and in the presence or absence of 5\% 2-mercaptoethanol. The sample was separated by electrophoresis through $12.5 \%$ polyacrylamide gels containing $0.1 \%$ gelatin (as substrate for proteolysis) at $25^{\circ} \mathrm{C}$, as described by Macedo et al. (2004). After electrophoresis, the gels were immersed in water containing $2.5 \%$ of Triton X-100 (renaturing solution) and gently shaken for $30 \mathrm{~min}$ at $25^{\circ} \mathrm{C}$ to wash out the SDS and allow protein renaturation. The gels were then incubated in $50 \mathrm{mM}$ PBS (pH 6.0) containing $3 \mathrm{mM}$ DTT and $2 \mathrm{mM}$ EDTA for $3 \mathrm{~h}$ at $37^{\circ} \mathrm{C}$. The incubated gels were stained with $0.2 \% \mathrm{Coo}-$ massie brilliant blue R-350 in 40\% methanol and 10\% acetic acid followed by treatment using the same solution without the dye. Enzymatic activity was detected as transparent bands by direct observation.

Statistical analysis - Results are reported as mean \pm SEM for triplicates. Statistical significance $(\mathrm{p}<0.05$ or $p<0.001)$ was assessed by analysis of variance followed by Tukey's test.

\section{RESULTS}

Protein content and larvicidal activity of latex flu$i d s$ - The quantities of soluble protein in LP fractions were initially estimated by the principle of protein-dye binding (Bradford 1976). The latex of C. procera was the richest in protein, while $C r$. grandiflora and $P$. rubra showed moderate levels. On the other hand, neither soluble protein nor proteolytic activity against azocasein or BANA was detected in E. tirucalli material (Table I). This result was further confirmed by electrophoresis (Fig. 1). Proteolytic activity was found in the LP of $\mathrm{Cr}$. grandiflora and P. rubra by photocolourimetric assay using azocasein (Table I) and by zymography using gelatin as the substrate (Fig. 1). As previously demonstrated (Freitas et al 2007, Oliveira et al. 2007), the LP of $C$. procera were active on both systems. It is noteworthy that $\mathrm{Cr}$. grandiflora, when assayed under identical con-

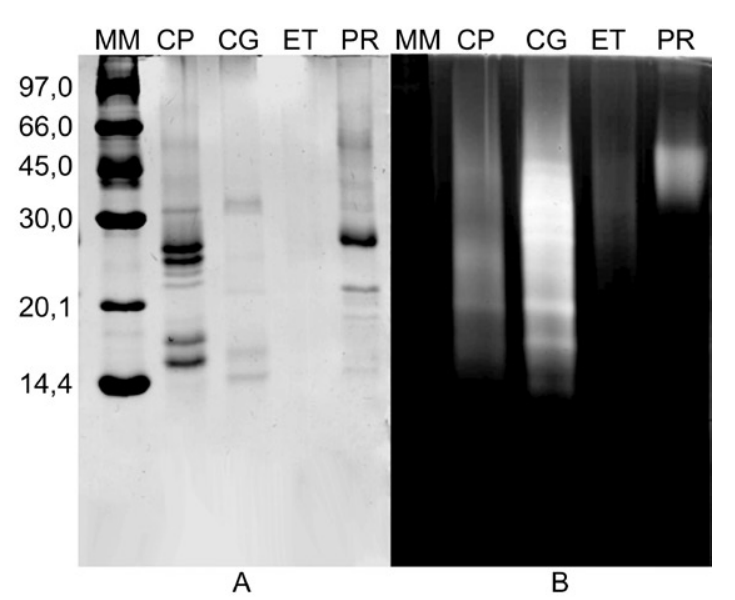

Fig. 1: electrophoresis (A) and Zymogram (B) of laticifer proteins (LP) of Calotropis procera (CP), Cryptostegia grandiflora (CG), Euphorbia tirucalli (ET) and Plumeria rubra (PR). A total of $5 \mu \mathrm{g}$ of LP was applied in the gel in all cases. Strongest proteolytic activity is seen in CG (panel B) while ET exhibited residual activity. MM: molecular mass markers. 
ditions using BANA as the substrate, exhibited a proteolytic activity 32 -fold higher than that of $C$. procera and 57-fold higher than that of P. rubra. Since BANA is a specific substrate for EC 3.4.22 (Barrett 1972), this activity likely predominates in the studied protein materials. In fact, cysteine proteinase activity is the only proteolytic activity found in LP from $\mathrm{Cr}$. grandiflora (CgLP), whereas LP from P. rubra (PrLP) exhibit poor cysteine and serine proteinase activity and completely lack aspartic and metallo-proteinase activity (data not shown). A detailed study of the protein profile and enzymatic antioxidative and proteolytic activities of CgLP, PrLP and laticifer proteins of E. tirucalli (EtLP) will appear elsewhere. The abundance of proteolytic activity in both $C r$. grandiflora and $C$. procera LP prompted us to further analyse these samples in an attempt to correlate larvicidal effects and proteolytic activity.

LP did not prevent egg hatching when assayed at 1 $\mathrm{mg} / \mathrm{mL}$ (Table II). However, the effect on larval growth was markedly different among the LP samples. Both, $C$. procera and $\mathrm{Cr}$. grandiflora exhibited strong toxicity to larvae, while E. tirucalli and P. rubra displayed fair activity, being similar to the controls. These data were recorded at the end of the observation period ( 72 h) and thus it appears that LP act on larvae rather than eggs. There was a correlation between the toxicity of LP sample and the amount of proteolytic activity (Table I). Samples exhibiting stronger proteolytic activity also showed higher toxicity to larvae (Table III).

Correlations between larvicidal effects and cysteine proteinase activity - LP of Cr. grandiflora were very effective in eliminating third instars of Ae. aegypti (Table III). E. tirucalli had moderate activity, while P. rubra was inactive. LP of C. procera and Cr. grandiflora were tested at different concentrations in the presence and absence of DTT (an efficient activator of EC 3.4.22) and E-64 (a specific and potent inhibitor of this activity). We observed that increasing concentrations of $C$. procera LP elevated the mortality of third instars. This effect was substantially augmented after treating the LP with DTT, suggesting the involvement of cysteine proteinase activity in the deleterious effects upon larvae. Furthermore, the larvicidal activities of $C$. procera $(\mathrm{CpLP})$ and $\mathrm{CgLP}$ were drastically reduced when the samples were pretreated with IAA, an irreversible inhibitor of EC 3.4.22,

\section{TABLE I}

Protein content and proteolytic activity of studied laticifer fluids

\begin{tabular}{|c|c|c|c|}
\hline $\begin{array}{l}\text { Protein samples }^{a} \\
\text { (laticifer proteins) }\end{array}$ & $\begin{array}{l}\text { Protein content }{ }^{b} \\
\quad(\mu \mathrm{g} / 100 \mu \mathrm{L})\end{array}$ & 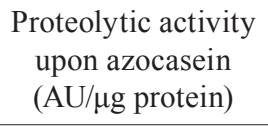 & 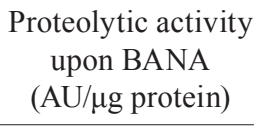 \\
\hline Calotropis procera ${ }^{c}$ & $132.0 \pm 3.9$ & $0.30 \pm 0.03$ & $0.42 \pm 0.00$ \\
\hline Cryptostegia grandiflora & $22.8 \pm 9.1$ & $3.27 \pm 0.13$ & $15.0 \pm 0.73$ \\
\hline Plumeria rubra & $41.8 \pm 1.7$ & $0.74 \pm 0.07$ & $0.26 \pm 0.02$ \\
\hline Euphorbia tirucalli & nd & nd & nd \\
\hline
\end{tabular}

$a$ : samples were pre-treated with dithiothreitol (DTT) to activate cysteine proteinases; AU: activity unit; $b$ : estimated according to Bradford method (1976); BANA: N- $\alpha$-benzoyl-DL-arginine $\beta$-naphthylamide hydrochloride; $c$ : $C$. procera was used as reference; nd: not detected. Results are expressed as mean \pm SD of six independent measurements.

\section{TABLE II}

Effects of laticifer proteins upon egg hatching of Aedes aegypti

\begin{tabular}{lccccc}
\hline $\begin{array}{l}\text { Samples } \\
(1 \mathrm{mg} / \mathrm{mL})\end{array}$ & $\begin{array}{c}\text { Eggs observed } \\
\mathrm{n}\end{array}$ & $\begin{array}{c}\text { Hatching after } 24 \mathrm{~h} \\
\%\end{array}$ & $\begin{array}{c}\text { Larvae (alive) after } 72 \mathrm{~h} \\
\mathrm{n}(\%)\end{array}$ & $\begin{array}{c}\text { Larvae(dead)after } 72 \mathrm{~h} \\
\mathrm{n}\end{array}$ & $\begin{array}{c}\text { Mortality } \\
(\%)\end{array}$ \\
\hline Ethanol $(1 \%)$ & $103.67 \pm 2.73$ & $88.26 \pm 7.42^{a}$ & $76.00 \pm 6.66(73.3)$ & $15.67 \pm 2.72$ & $17.00 \pm 1.49^{a}$ \\
BSA & $132.50 \pm 11.03$ & $48.44 \pm 9.77^{b}$ & $52.50 \pm 10.21(81.7)$ & $13.00 \pm 5.72$ & $18.5 \pm 4.49^{a}$ \\
CpLP & $130.00 \pm 13.06$ & $65.65 \pm 2.56^{a}$ & $13.66 \pm 4.91(10)$ & $72.33 \pm 15.95$ & $82.00 \pm 8.89^{b}$ \\
CgLP & $106.33 \pm 3.76$ & $86.75 \pm 8.43^{a}$ & $1.33 \pm 0.33(1.2)$ & $90.33 \pm 6.77$ & $98.33 \pm 0.66^{b}$ \\
EtLP & $104.66 \pm 3.28$ & $93.95 \pm 5.11^{a}$ & $72.00 \pm 5.69(68.7)$ & $26.66 \pm 5.37$ & $27.33 \pm 5.24^{a}$ \\
PrLP & $116.33 \pm 13.02$ & $91.93 \pm 4.05^{a}$ & $84.66 \pm 8.96(72.9)$ & $22.00 \pm 1.53$ & $20.66 \pm 2.18^{a}$ \\
\hline
\end{tabular}

Values are means \pm SEM of triplicates. Different letters in the same column differ significantly $(\mathrm{p}<0.05$ for hatching and $\mathrm{p}<0.001$ for mortality data) from the control (ethanol 1\%). Statistical significance was assessed by analysis of variance followed by Tukey's test. BSA: bovine serum albumin; CgLP: laticifer proteins of Cryptostegia grandiflora; CpLP: laticifer proteins of Calotropis procera; EtLP: laticifer proteins of Euphorbia tirucalli; PrLP: laticifer proteins of Plumeria rubra. 
compared to corresponding samples that had been activated with DTT to get maximum proteolysis (Table III). DTT, E-64 and IAA did not exhibit toxicity at the concentrations at which they were assayed (data not shown). The fact that $C r$. grandiflora and $C$. procera were highly active while E. tirucalli and P. rubra showed negligible effects on larvae also supports the hypothesis that proteolytic activity is involved in the deleterious effects. $\mathrm{Cr}$. grandiflora, which exhibited stronger proteolytic activity (Table I), was also more active than the $C$. procera samples (Table III).

To emphasise the importance of cysteine proteinase activity for larval toxicity, EC 3.4.22.2 (obtained from Sigma), a cysteine proteinase purified from the latex of C. papaya (Caricaceae), was assayed (Nitsawang et al. 2006). We found that the proteolytic activity of EC 3.4.22.2 was inhibited by E-64 (Fig. 2). Table IV summarises the larvicidal effects of EC 3.4.22.2, which exhibited toxic effects upon third instars, mainly after activation by DTT. This effect was drastically reduced when the enzyme was inhibited by E-64. According to the results, there seems to be a direct correlation between the proteolytic activity of this cysteine proteinase of laticifer origin and toxicity to Ae. aegypti larvae. EC 3.4.21.4 and EC 3.4.21.1, both serine proteinases, were assayed for larvicidal activity at 0.05 and $0.1 \mathrm{mg} / \mathrm{mL}$ (Kraut 1977). The proteolytic activity of these enzymes $(0.1 \mathrm{mg} / \mathrm{mL})$ against azocasein was estimated to be 4.7 and $2.0 \mathrm{AU} /$ $\mu \mathrm{g}$, respectively. These values are similar to that of EC 3.4.22.2 (3.2 AU/ug) (Fig. 2). However, the serine proteinases did not exhibit any larvicidal effects (Table IV). Similarly, no larval mortality was documented when larvae were exposed to PBS alone.

\section{DISCUSSION}

Through the years, the dengue mosquito has become progressively adapted to human civilisation. This trend, which has been confirmed by health agents involved in governmental programs for dengue combat, is evidenced by the number of cases of the disease reported by the World Health Organisation (PAHO/WHO 2008), which has increased drastically mainly in urban areas. Consequently, the use of traditional chemical organophosphorates is not necessarily the best strategy to combat the mosquito. The dissemination of these insecticides in the air does not effectively kill mosquitoes in dwellings and cannot be used indoors due to side effects and general toxicity. An alternative or complementary strategy should include the use of novel bioactive compounds with lower toxicities that are able to

TABLE III

Larvicidal effect of laticifer proteins upon third instars of Aedes aegypti

\begin{tabular}{|c|c|c|c|}
\hline \multirow[b]{2}{*}{ Samples } & \multicolumn{3}{|c|}{ Mortality (\%) } \\
\hline & $3 \mathrm{~h}$ & $24 \mathrm{~h}$ & $48 \mathrm{~h}$ \\
\hline Ethanol (1\%) & $0 \pm 0.0^{a}$ & $0 \pm 0.0^{a}$ & $0 \pm 0.0^{a}$ \\
\hline $\operatorname{BSA}(1 \mathrm{mg} / \mathrm{mL})$ & $0 \pm 0.0^{a}$ & $0 \pm 0.0^{a}$ & $0 \pm 0.0^{a}$ \\
\hline CpLP $(0.1 \mathrm{mg} / \mathrm{mL})$ & $0 \pm 0.0^{a}$ & $3.33 \pm 3.33^{a}$ & $6.66 \pm 3.33^{a}$ \\
\hline CpLP + DTT $(0.1 \mathrm{mg} / \mathrm{mL})$ & $0 \pm 0.0^{a}$ & $10.00 \pm 5.77^{a}$ & $36.66 \pm 6.67^{b}$ \\
\hline CpLP $(0.25 \mathrm{mg} / \mathrm{mL})$ & $0 \pm 0.0^{a}$ & $3.33 \pm 3.33^{a}$ & $13.33 \pm 3.33^{a}$ \\
\hline CpLP + DTT $(0.25$ mg/mL) & $0 \pm 0.0^{a}$ & $16.67 \pm 3.33^{a}$ & $40.0 \pm 5.78^{b}$ \\
\hline CpLP (1 mg/mL) & $0 \pm 0.0^{a}$ & $30.0 \pm 10.00^{a}$ & $56.66 \pm 3.33^{b}$ \\
\hline CpLP + DTT (1 mg/mL) & $0 \pm 0.0^{a}$ & $80.0 \pm 11.56^{b}$ & $100.0 \pm 0.0^{b}$ \\
\hline CpLP (2 mg/mL) & $0 \pm 0.0^{a}$ & $56.66 \pm 16.67^{b}$ & $70.0 \pm 10.00^{b}$ \\
\hline CpLP + DTT (2 mg/mL) & $0 \pm 0.0^{a}$ & $90 \pm 5.78^{b}$ & $100 \pm 0.00^{b}$ \\
\hline $\mathrm{CPLP}+\mathrm{DTT}+\mathrm{E}-64(2 \mathrm{mg} / \mathrm{mL})$ & $0 \pm 0.0^{a}$ & $60.0 \pm 10.0^{b}$ & $87.0 \pm 8.83^{b}$ \\
\hline CpLP (2 mg/mL + IAA) & $0 \pm 0.0^{a}$ & $13.00 \pm 8.82^{b}$ & $60 \pm 0.00^{b}$ \\
\hline $\mathrm{CgLP}(1 \mathrm{mg} / \mathrm{mL})$ & $0 \pm 0.0^{a}$ & $83.33 \pm 3.33^{b}$ & $96.66 \pm 3.33^{b}$ \\
\hline $\mathrm{CgLP}+\mathrm{DTT}+\mathrm{E}-64(1 \mathrm{mg} / \mathrm{mL})$ & $0 \pm 0.0^{a}$ & $0 \pm 0.0^{a}$ & $36.66 \pm 6.67^{b}$ \\
\hline $\operatorname{CgLP}(0.25 \mathrm{mg} / \mathrm{mL})$ & $10.00 \pm 1.44^{b}$ & $90.00 \pm 5.78^{b}$ & $93.33 \pm 3.33^{b}$ \\
\hline $\mathrm{CgLP}(0.25 \mathrm{mg} / \mathrm{mL}+\mathrm{DTT})$ & $0 \pm 0.0^{a}$ & $100 \pm 0.0^{b}$ & $100 \pm 0.00^{b}$ \\
\hline CgLP (1mg/mL + IAA) & $0 \pm 0.0^{a}$ & $0 \pm 0.0^{a}$ & $21.42 \pm 15.28^{a}$ \\
\hline EtLP $(1 \mathrm{mg} / \mathrm{mL})$ & $0 \pm 0.0^{a}$ & $0 \pm 0.0^{a}$ & $16.66 \pm 3.33^{a}$ \\
\hline PrLP (1 mg/mL) & $0 \pm 0.0^{a}$ & $0 \pm 0.0^{a}$ & $0 \pm 0.0^{a}$ \\
\hline
\end{tabular}

Values are means \pm SEM of triplicates. Different letters in the same column differ significantly $(\mathrm{p}<0.05)$ from the control (ethanol $1 \%$ ). Statistical significance was assessed by analysis of variance followed by Tukey's test. Laticifer proteins of Calotropis procera $(\mathrm{CpLP})$ and laticifer proteins of Cryptostegia grandiflora (CgLP) were assayed solely, activated with dithiothreitol (DTT) and inhibited with trans-epoxysuccinyl-1-leucylamido (4-guanidio)-butane (E-64) or iodoacetamide (IAA). No mortality was observed after 1 h. BSA: bovine serum albumin; EtLP: laticifer proteins of Euphorbia tirucalli; PrLP: laticifer proteins of Plumeria rubra. 


\section{TABLE IV}

Larvicidal effect of the commercially available cysteine (papain) and serine (trypsin and chymotrypsin) proteinases upon third instars of Aedes aegypti

\begin{tabular}{|c|c|c|c|c|c|c|}
\hline \multirow{4}{*}{ Samples } & \multicolumn{6}{|c|}{ Mortality (\%) } \\
\hline & \multicolumn{2}{|c|}{ Not activated with DTT } & \multicolumn{2}{|c|}{ Activated with DTT } & \multicolumn{2}{|c|}{ Papain + DTT + E-64 } \\
\hline & \multicolumn{6}{|c|}{ Time of observation (hours) } \\
\hline & 24 & 48 & 24 & 48 & 24 & 48 \\
\hline Ethanol (1\%) & $0 \pm 0.0^{a}$ & $3.33 \pm 3.33^{a}$ & - & - & - & - \\
\hline BSA $(2 \mathrm{mg} / \mathrm{mL})$ & $3.33 \pm 3.33^{a}$ & $6.67 \pm 3.33^{a}$ & - & - & - & - \\
\hline Papain $(0.01 \mathrm{mg} / \mathrm{mL})$ & $0 \pm 0.0^{a}$ & $0 \pm 0.0^{a}$ & $13.33 \pm 3.33^{a}$ & $36.66 \pm 3.33^{b}$ & na & na \\
\hline Papain $(0.025$ mg/mL) & $3.33 \pm 3.33^{a}$ & $16.67 \pm 12.25^{a}$ & $10.0 \pm 5.77^{a}$ & $63.33 \pm 6.67^{b}$ & na & na \\
\hline Papain $(0.05$ mg/mL) & $0 \pm 0.0^{a}$ & $16.67 \pm 8.80^{a}$ & $43.33 \pm 13.35^{b}$ & $86.70 \pm 8.12^{b}$ & $6.66 \pm 3.33^{a}$ & $10.00 \pm 5.77^{a}$ \\
\hline Trypsin $(0.05$ mg/mL) & $0 \pm 0.0^{a}$ & $0 \pm 0.0^{a}$ & - & - & - & - \\
\hline Trypsin $(0.1 \mathrm{mg} / \mathrm{mL})$ & $0 \pm 0.0^{a}$ & $0 \pm 0.0^{a}$ & - & - & - & - \\
\hline Chymotrypsin $(0.05$ mg/mL) & $0 \pm 0.0^{a}$ & $0 \pm 0.0^{a}$ & - & - & - & - \\
\hline Chymotrypsin $(0.1 \mathrm{mg} / \mathrm{mL})$ & $0 \pm 0.0^{a}$ & $0 \pm 0.0^{a}$ & - & - & - & - \\
\hline
\end{tabular}

Values are means \pm SEM for two independent experiments. Statistical significance $(\mathrm{p}<0.05)$ was assessed by analysis of variance followed by Tukey's test. Different letters in the same column differ significantly from control (ethanol 1\%). BSA: bovine serum albumin; DTT: dithiothreitol; E-64: trans-epoxysuccinyl-1-leucylamido (4-guanidio)-butane; na: not assayed.

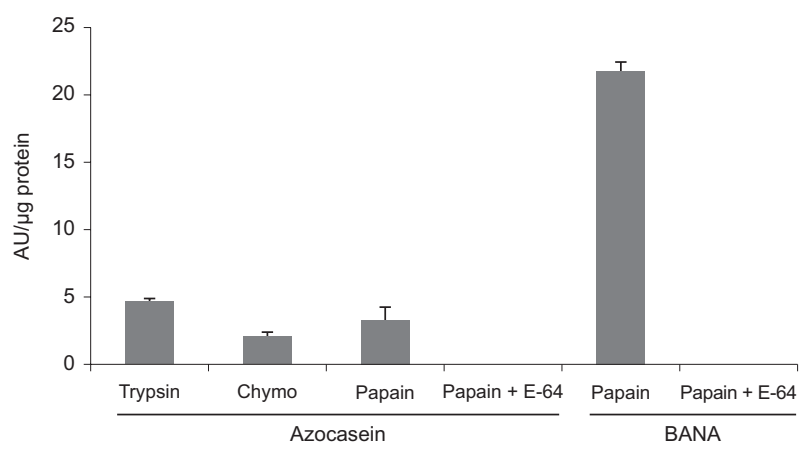

Fig. 2: proteolytic activity of commercially available cysteine (papain) and serine (trypsin and chymotrypsin) proteinases and inhibition of the proteolytic activity of papain from Carica papaya latex. The samples were also used to investigate toxic effects upon third instars of Aedes aegypti as shown in Table IV. AU: unit of activity; BANA: $N$ - $\alpha$-benzoyl-DL-arginine $\beta$-naphthylamide hydrochloride; E-64: trans-epoxysuccinyl-1-leucylamido (4-guanidio)-butane.

efficiently eliminate dengue foci in inhabited areas. In this context, bioactive proteins may serve as potential alternative. In this paper, we advanced the idea of using bioactive proteins to destroy mosquito larvae and thus reduce mosquito proliferation.

Latex-producing plants are widespread in different habitats. These plants usually secrete milk-like fluid from a network of laticifer cells, in which subcellular organelles intensively synthesise proteins and secondary metabolites (Lopes et al. 2009). The biological importance of latex fluids is still unclear and knowledge of their physiological role is still limited (Ramos et al. 2007).
Nevertheless, proteolytic activity has been described as a common and frequently abundant endogenous enzymatic activity in many laticifer fluids (Glazer \& Smith 1971, Lynn 1979, Boller 1986, Freitas et al. 2007). Serine and EC 3.4.22 have been reported as the most common proteinases found in laticifer fluids and the latter was largely predominant in the materials tested in the present paper, in which three out of four latex fluids analysed showed proteolytic activity. Plant EC 3.4.22 play major roles in intracellular and extracellular processes such as the development and ripening of fruits (Brady 1985), the building of nutritional reserves, the degradation of storage proteins in germinating seeds (Kembhavi et al. 1993, Taylor \& Cuming 1993), the activation of pro-enzymes and the degradation of defective proteins (Rudenskaya et al. 1998). Additionally, enzymes in latex are involved protecting the plant against predator attack (Smith et al. 1955, Boller 1986).

The study performed here suggests that LP EC 3.4.22 may be involved in the larvicidal action against Ae. aegypti. However, data in the literature associating larvicidal or insecticidal action with proteolytic activity are scarce. Most of the available data deal with insecticidal plant proteins such as lectins, ribosome-inactivating proteins, enzyme inhibitors, arcelins, chitinases, ureases and modified storage proteins (Carlini \& Grossi-de-Sá 2002). On the other hand, Pechan et al. (2002) have described a correlation between the impaired growth of caterpillars and a cysteine proteinase present in some Maize (Zea mays L.) lines that are resistant to feeding by a number of lepidopteran species. The insect's peritrophic matrix was severely damaged when caterpillars fed on these resistant maize plants or transgenic sweet corn containing the gene encoding the cysteine proteinase. The accumulation 
of the cysteine proteinase in response to caterpillar feeding and its ability to damage the insect peritrophic matrix represents an unusual plant defence mechanism that may have applications in biotechnology. Thus, it is reasonable to think that EC 3.4.22 present in LP may destroy larvae of Ae. aegypti by disrupting their peritrophic matrix. However, the remaining larvicidal activity still detected in samples inhibited with IAA or E-64 suggests that other proteins in these latex samples may also be implicated in the larvicidal action. It is also relevant to consider the larvicidal effect of EC 3.4.22.2, which is a cysteine proteinase obtained from another latex. The results shown in Table IV give important insights about the contribution of the EC 3.4.22 to larval death. Further studies of the effects of purified EC 3.4.22 from C. procera or $\mathrm{Cr}$. grandiflora on larval development will certainly help to clarify the remaining questions.

Interestingly, we found that LP did not cause damage to mosquito eggs; in fact, egg hatching in LP-treated samples was as intense as in the controls. This ineffectiveness may be due to the low doses of LP used (1 mg/ $\mathrm{mL}$ ). LP from $C$. procera have been shown to almost completely inhibit egg hatching at doses of $10 \mathrm{mg} / \mathrm{mL}$ (Ramos et al. 2006). This dose was not used in the present study due to the limited amounts available to perform assays with P. rubra and Cr. grandiflora. Thus, the action of LP from Cr. grandiflora on egg hatching remains to be established, though the deleterious effects of LP from C. procera on eggs are well-defined.

This work provides strong evidence for the involvement of proteases in the larvicidal effects of LP. Independent of the botanical source of these enzymes, they may serve as an alternative or complementary strategy to combat dengue and modern molecular biological techniques could be applied to produce the active compound. Among our strategies, we are formulating a protocol to obtain callus tissues from $C$. procera and test them for larvicidal and proteolytic activity. The potential toxicity of proteins from $\mathrm{Cr}$. grandiflora remains to be investigated. Concerning C. procera, the whole latex has been described as a rich source of toxic compounds (El-Badwi et al. 1998). However, the experimental evidence we have accumulated suggests that the toxic compounds of the $C$. procera latex are lost during dialysis and centrifugation (Alencar et al. 2006). The protein fraction of the latex of CpLP was also shown to be non-toxic to normal cells (Oliveira et al. 2007).

In conclusion, our results show that cysteine proteinase activity is involved in the larvicidal action of latex proteins and the LP of Cr. grandiflora (and, to a lesser extent, $P$. rubra) can effectively eliminate Ae. aegypti larvae.

\section{ACKNOWLEDGMENTS}

To Núcleo de Endemias Transmissíveis por Vetores, Secretaria de Saúde do Estado do Ceará (Brasil), for providing eggs and larvae of Ae. aegypti.

\section{REFERENCES}

Abe M, Abe K, Kuroda S, Arai S 1992. Corn Kernel cysteine proteinase inhibitor as a novel cystatin superfamily member of plant origin. Molecular cloning and expression studies. Eur J Biochem 209: 933-937.
Alencar NMN, Oliveira JS, Mesquita RO, Lima MW, Vale MR, Etchells JP, Freitas CD, Ramos MV 2006. Pro and anti-inflammatory activities of the latex from Calotropis procera (Ait.) R.Br. are triggered by compounds fractionated by dialysis. Inflamm Res 55: 559-564.

Barrett AJ 1972. A new assay for cathepsin $\mathrm{B}_{1}$ and other thiol proteinases. Anal Biochem 47: 280-293.

Boller T 1986. Roles of proteolytic enzymes in interaction of plant and other organisms. In MJ Dalling, Plant proteolytic enzymes, CRC Press, Boca Raton, p. 67-96.

Bradford MM 1976. A rapid and sensitive method for the quantification of microgram quantities of proteins utilizing the principle of protein-dye binding. Anal Biochem 72: 248-254.

Brady CJ 1985. Fruit ripening. Annu Rev Plant Physiol 38: 155-178.

Braga IA, Valle D 2007. Aedes aegypti: inseticidas, mecanismos de ação e resistência. Epidemiol Serv Saude 16: 279-293.

Carlini CR, Grossi-de-Sá MF 2002. Plant toxic proteins with insecticidal properties. A review on their potentialities as bioinsecticides. Toxicon 40: 1515-1539.

Carvalho AFFU, Melo VMM, Machado MIL, Bantim MB, Rabelo EF 2003. Larvicidal activity of the essential oil from Lippia sidoides Cham. against Aedes aegypti Linn. Mem Inst Oswaldo Cruz 98: 569-571.

Consoli RA, Oliveira RL 1994. Principais mosquitos de importância sanitária no Brasil, Fiocruz, Rio de Janeiro, 225 pp.

El-Badwi, Samia MA, Adam SE, Shigidi MT, Hapke HJ 1998. Studies on laticiferous plants: toxic effects in goats of Calotropis procera latex given by different routes of administration. Dtsch Tierarztl Wochenschr 105: 425-427.

Freitas CDT, Oliveira JS, Miranda MRA, Macedo NMR, Sales MP, Vilas-Boas LA, Ramos MV 2007. Enzymatic activities and protein profile of latex from Calotropis procera. Plant Physiol Biochem 45: 781-789.

Glazer AN, Smith EL 1971. Papain and other plant sulfhydryl proteolytic enzymes. In PD Boyer, The enzymes, Academic Press, New York, p. 501-546.

Kembhavi AA, Buttle DJ, Knight CG, Barrett AJ 1993. The two cysteine endopeptidases of legume seeds: purification and characterization by use of specific fluorometric assay. Arch Biochem Biophys 303: 208-213.

Kraut J 1977. Serine proteases: structure and mechanism of catalysis. Annu Rev Biochem 46: 331-358.

Laemmli UK 1970. Cleavage of structural proteins during the assemble of bacteriophage $\mathrm{T}_{4}$. Nature 227: 680-688.

Lopes KLB, Thadeo M, Azevedo AA, Soares AA, Meira RMSA 2009. Articulated laticifers of vegetative organs Mandevilla atroviolaceae (Apocynaceae, Apocynoideae). Botany 87: 202-209.

Lynn KR 1979. Purification and some properties of two proteases from papaya latex. Biochim Biophys Acta 569: 193-201.

Macedo ML, Freire MD, Parra JRP 2004. Kunitz-type inhibitor of coleopteran proteases, isolated from Adenanthera pavonina L. seeds and its effect on Callosobruchus maculatus. J Agric Food Chem 52: 2533-2540.

Nitsawang S, Hatti-Kaul R, Kanasawuda P 2006. Purification of papain from Carica papaya latex: aqueous two-phase extraction versus two-step salt precipitation. Enzyme Microb Technol 39: 1103-1107.

Oliveira JS, Bezerra DP, Freitas CDT, Marinho-Filho JDB, Moraes MO, Pessoa C, Costa-Lotufo LV, Ramos MV 2007. In vitro 
cytotoxicity against different human cancer cell lines of laticifer proteins of Calotropis procera (Ait.) R.Br. Toxicol In Vitro 21: $1563-1573$.

PAHO/WHO - Pan American Health Organization (PAHO) and World Health Organization (WHO) 2008. [database on the internet]. Brasilia (DF): Brazil health systems and services profile: monitoring and analysis of health systems change/reform. Organization. [cited 2009 Apr 29]. Available from: http://www. lacheathsys.org.

Patel BK, Jagannadham MV 2003. A high cysteine containing thiol proteinase from the latex of Ervatamia heyneana: purification and comparison with Ervatamin B and C from Ervatamia coronaria. J Agric Food Chem 51: 6326-6334.

Pechan T, Cohen A, Williams WP, Luthe DS 2002. Insect feeding mobilizes a unique plant defense protease that disrupts the peritrophic matrix of caterpillars. Proc Natl Acad Sci 99: 13319-13323.

Porter AG 1996. Mosquitocidal toxins genes and bacteria: the hit squad. Parasitol Today 12: 175-179.

Ramos MV, Bandeira GP, Freitas CDT, Nogueira NAP, Alencar NMN, Sousa PAS, Carvalho AFFU 2006. Latex constituents from Calotropis procera (Ait.) R.Br. display toxicity upon egg hatching and larvae of Aedes aegypti (Linn.). Mem Inst Oswaldo Cruz 101: 503-510.

Ramos MV, Freitas CDT, Stanisçuaski F, Macedo LLP, Sales MP, Sousa DP, Carlini CR 2007. Performance of distinct crop pests reared on diets enriched with latex proteins from Calotropis procera: role of laticifer proteins in plant defense. Plant Sci 173: 349-357.
Rudenskaya GN, Bogacheva AM, Preusser A, Kuznetsova AV, Dunaevsky YE, Golovkin BN, Stepanov VM 1998. Taraxalisin-A serine proteinase from dandelion, Taraxacum officinale. FEBS Lett 437: 237-240.

Schagger H, Jagow GV 1987. Tricine-sodium dodecyl sulfatepolyacrylamide gel electrophoresis for the separation of proteins in the range from 1 to $100 \mathrm{KDa}$. Anal Biochem 166: 368-379.

Siqueira Jr JB, Martelli CMT, Coelho GE, Simplício ACR, Hatch DL 2005. Dengue and dengue hemorrhagic fever, Brazil, 1981-2002. Emerg Infect Dis 11: 48-53.

Smith EL, Kimmel JR, Brown DM, Thompson EOP 1955. Isolation and properties of crystalline mercury derivative of a lysozyme from papaya latex. $J$ Biol Chem 215: 67-89.

Taylor RM, Cumming AC 1993. Purification of an endoproteinase that digests the wheat "EM" protein in vitro and determination of its cleavage sites. FEBS Lett 331: 76-80.

WHO - World Health Organization 2005. Guidelines for laboratory and field testing of mosquito larvicides, WHO, Geneva, 39 pp.

WHO - World Health Organization 2009. [homepage on the internet]. Genebra: dengue/dengue haemorrhagic fever. [updated 2009 May 16; cited 2009 Apr 29]. Available from: http://www.who.int/ mediacentre/factsheets/ fs117/en/index.html.

Xavier-Filho J, Campos FAP, Ary MB, Silva CP, Carvalho MMM 1989. Poor correlation between the levels of proteinase inhibitors found in seeds of different cultivars of cowpea (Vigna unguiculata) and the resistance/susceptibility to predation by Callosobruchus maculatus. J Agric Food Chem 37: 1139-1143. 